\title{
Hbo'ers in tijden van corona
}

Citation for published version (APA):

Allen, J., Belfi, B., \& Aarts, B. (2020). Hbo'ers in tijden van corona. ROA. ROA Reports No. 002 https://doi.org/10.26481/umarep.2020002

Document status and date:

Published: $23 / 06 / 2020$

DOI:

10.26481/umarep.2020002

Document Version:

Publisher's PDF, also known as Version of record

\section{Please check the document version of this publication:}

- A submitted manuscript is the version of the article upon submission and before peer-review. There can be important differences between the submitted version and the official published version of record.

People interested in the research are advised to contact the author for the final version of the publication, or visit the DOI to the publisher's website.

- The final author version and the galley proof are versions of the publication after peer review.

- The final published version features the final layout of the paper including the volume, issue and page numbers.

Link to publication

\footnotetext{
General rights rights.

- You may freely distribute the URL identifying the publication in the public portal. please follow below link for the End User Agreement:

www.umlib.nl/taverne-license

Take down policy

If you believe that this document breaches copyright please contact us at:

repository@maastrichtuniversity.nl

providing details and we will investigate your claim.
}

Copyright and moral rights for the publications made accessible in the public portal are retained by the authors and/or other copyright owners and it is a condition of accessing publications that users recognise and abide by the legal requirements associated with these

- Users may download and print one copy of any publication from the public portal for the purpose of private study or research.

- You may not further distribute the material or use it for any profit-making activity or commercial gain

If the publication is distributed under the terms of Article $25 \mathrm{fa}$ of the Dutch Copyright Act, indicated by the "Taverne" license above, 
Maastricht University

\section{Hbo'ers in tijden van corona}

Jim Allen

Barbara Belfi

Bas Aarts

\section{ROA Rapport}

ROA-R-2020/2

Researchcentrum voor Onderwijs en Arbeidsmarkt | ROA Research Centre for Education and the Labour Market / ROA 


\title{
Colofon
}

(c) Researchcentrum voor Onderwijs en Arbeidsmarkt (ROA). Niets uit deze uitgave mag op enige manier worden verveelvoudigd zonder voorafgaande schriftelijke toestemming van de directeur van het ROA.

\author{
Researchcentrum voor Onderwijs en Arbeidsmarkt \\ Postbus 616 \\ 6200 MD Maastricht \\ $\mathrm{T}+31433883647$ \\ $\mathrm{F}+31433884914$ \\ secretary-roa-sbe@maastrichtuniversity.nl \\ www.roa.nl \\ School of Business and Economics \\ Maastricht University \\ Vormgeving \\ ROA secretariaat, Maastricht
}

ISBN: 978-90-5321-591-3

ISSN: 2666-8858

juni 2020 


\section{Inhoud}

\section{Samenvatting iii}

\section{Hbo'ers in tijden van corona 1}

1 Inleiding 1

2 Data en methoden 3

3 Verandering in maatschappelijke positie 4

4 Verandering in aantal gewerkte uren en beloning 5

5 Thuiswerken 8

6 Materiële zorgen 9

7 Uitvoering van werktaken

8 Gezondheid en stress 12

9 Situatie zelfstandigen 15

10 Situatie werklozen 16

11 Situatie studenten 16

12 Situatie anderen 17

13 Vertrouwen in overheidsaanpak en toekomst 18

14 Discussie en reflectie 20 


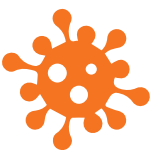




\section{Samenvatting}

\section{De uitkomsten in vogelvlucht}

In dit rapport doen we verslag van de resultaten van een enquêteonderzoek naar de gevolgen van de coronacrisis voor de arbeidsmarktsituatie, werkomstandigheden en het welbevinden van jonge hbo'ers die tussen 2013 en 2018 zijn afgestudeerd. Het enquêteonderzoek vond in mei 2020 plaats, en 15.815 hbo-afgestudeerden deden hieraan mee (respons: $33,3 \%$ ). Uit de resultaten blijkt dat ondanks dat de meeste afgestudeerde hbo'ers de eerste maanden van de COVID-19 crisis redelijk goed hebben weten te doorstaan, de gevolgen voor een deel van de afgestudeerden duidelijk zichtbaar zijn. 3,1\% van de afgestudeerden die op 31 januari nog werk hadden, waren vier maanden later werkloos. Daarnaast hebben veel werkenden hun werkuren moeten aanpassen. $23 \%$ werkte in mei minder dan op 31 januari en $20 \%$ juist meer. Zo'n 30\% van de afgestudeerden die minder uren zijn gaan werken hebben die uren niet doorbetaald gekregen, en $45 \%$ van de afgestudeerden die meer uren zijn gaan werken hebben de extra uren niet uitbetaald gekregen. Een groot deel van de afgestudeerden gaf aan in mei meer stress te ervaren dan voor de coronacrisis, zowel op het werk (34\%) als thuis (32\%). Daarnaast gaf $23 \%$ aan meer angst voor het verlies van werk te ervaren, en $14 \%$ aan meer financiële problemen te ondervinden. $47 \%$ gaf aan dat het sinds de crisis moeilijker is geworden om hun werktaken te verrichten.

Door de zeer gunstige arbeidsmarktpositie van hbo'ers vóór de corona-uitbraak is, ondanks deze veranderingen, de huidige situatie voor een duidelijke meerderheid nog altijd vrij goed. 4,6\% was in mei werkloos. Ter vergelijking: in 2013, op het hoogtepunt van de financiële crisis, was bijna $8 \%$ van de recent afgestudeerde hbo'ers werkloos. ${ }^{1}$ Men werkte in mei met gemiddeld 35 uur, nagenoeg een volledige werkweek. Bijna de helft (46\%) gaf bovendien aan tijdens de coronacrisis nieuwe ideeën te hebben opgedaan voor hun werk en $60 \%$ gaf aan vertrouwen te hebben in hoe de overheid met de crisis omgaat. Bijna de helft $(48 \%)$ verwachtte tot slot dat door de versoepeling van de overheidsmaatregelen hun leven de komende tijd beter zal worden.

De gevolgen van de coronacrisis blijken echter niet evenredig te zijn verdeeld over verschillende subgroepen hbo'ers. Hieronder geven we een overzicht van de groepen die op verschillende fronten het zwaarst zijn getroffen door de coronacrisis. Dit houdt in dat deze groepen op diverse gebieden substantieel meer problemen ervaren ten gevolge van de coronacrisis, ten opzichte van het populatiegemiddelde. ${ }^{2}$

1 Belfi, B., Allen, J., van Eldert, P., de Grip, A., Künn, A., Peeters, T., \& Poulissen, D. (2018). Schoolverlaters in crisistijd: Gevolgen voor leren en de vroege loopbaan. Research Centre for Education and the Labour Market. ROA Reports, No. 007

2 We vermelden in dit rapport enkel groepsverschillen die significant zijn op 1\%-niveau en die meer dan 10\% afwijken van het populatiegemiddelde. 


\section{Beroep}

Allereerst blijken afgestudeerden werkzaam in artistieke beroepen beduidend zwaarder te zijn getroffen door de coronacrisis dan afgestudeerden van andere sectoren. Meer dan de helft van de werkenden in artistieke beroepen (58\%) gaf in mei aan een toename in angst voor verlies van werk te ervaren en $39 \%$ gaf aan meer financiële problemen te hebben dan voor de coronacrisis. Bijna de helft (48\%) van de werkenden in deze beroepen gaf aan minder uren te werken tijdens de crisis dan ervoor. Zo'n $67 \%$ van de werkenden in artistieke beroepen die minder uren zijn gaan werken hebben die uren niet doorbetaald gekregen, en 55\% van de groep die meer uren zijn gaan werken hebben die extra uren niet uitbetaald gekregen. Werkenden in deze beroepen gaven bovendien aan met beduidend meer stress thuis te kampen dan voor de crisis (36\%). $55 \%$ was van mening dat hun werktaken door de coronacrisis moeilijker zijn geworden en een minderheid (45\%) gaf aan vertrouwen te hebben in hoe de overheid omgaat met de crisis.

Ook hbo'ers werkzaam in onderwijskundige beroepen zijn bovengemiddeld geraakt door de crisis. Ruim $60 \%$ van de werkenden in deze beroepen gaf aan dat door de coronacrisis hun werkuren zijn veranderd. Hierbij werd ongeveer even vaak aangegeven dat men tijdens de crisis meer uren was gaan werken (33\%), als minder uren (28\%). Veel werkenden in onderwijskundige beroepen (40\%) gaven verder aan meer werkstress dan voor de crisis te ervaren, en $61 \%$ gaf aan dat hun werktaken moeilijker zijn geworden door de crisis. Anderzijds gaf maar liefst $73 \%$ van de werkenden in onderwijskundige beroepen aan door de crisis nieuwe ideeën te hebben opgedaan voor hun werk.

Ook voor werkenden in hulpverlenende beroepen en gezondheidszorgberoepen zijn de gevolgen van de coronacrisis duidelijk voelbaar, vooral op het gebied van werkstress en moeilijkheden bij het uitvoeren van de werktaken. $43 \%$ gaf aan in mei meer stress te ervaren op het werk dan voor de coronacrisis, en $63 \%$ gaf aan dat hun werktaken sinds de coronacrisis moeilijker zijn geworden. Bij gezondheidszorgberoepen gaf ook $43 \%$ aan meer werkstress te ervaren dan voor de crisis, terwijl $53 \%$ van mening was dat hun werktaken moeilijker zijn geworden.

Ook de dienstverlenende beroepen (bv. horeca) zijn bovengemiddeld sterk geraakt door de crisis. Op moment van enquêtering gaf een relatief groot deel (39\%) van de werkenden in deze beroepen aan minder uren te werken dan voor de crisis. Bovendien ervoeren veel werkenden in deze beroepsgroep een toename in werkstress (42\%) en angst voor het verlies van werk (47\%) ten gevolge van de crisis. Daarnaast gaf bijna een kwart (22\%) aan meer financiële problemen te ervaren dan vóór de coronacrisis.

Tot slot gaven werkenden in commerciële of zakelijke beroepen bovengemiddeld vaak aan een toename in angst voor verlies van werk te ervaren (31\%). Echter, de meerderheid van de werkenden in deze beroepen (55\%) verwachtte dat hun situatie op termijn zal worden verbeterd door de versoepelingen van de overheidsmaatregelen. 
Hbo-sector

Veel hbo-opleidingen leiden hun studenten op voor een specifiek werkveld. Om deze reden komen de ervaringen van afgestudeerden van een bepaalde hbo-sector en de ervaringen van werkenden in de beroepen die gelieerd zijn aan deze hbo-sector doorgaans sterk overeen. Zo ervaren afgestudeerden van de hbo-sector Kunst vaak dezelfde problemen als zijn beschreven voor werkenden in artistieke beroepen, afgestudeerden van de sector Onderwijs meestal dezelfde problemen als zijn beschreven voor werkenden in onderwijskundige beroepen, en afgestudeerden van de sectoren Gezondheidszorg en Sociale Studies gelijkaardige problemen als afgestudeerden die in respectievelijk gezondheidszorg- en hulpverlenende beroepen werkzaam zijn. Deze ervaringen zijn vooral te herleiden tot het soort werk dat wordt uitgevoerd, en zeggen derhalve als zodanig niets over (de kwaliteit van) de gevolgde opleidingen. Uitzondering op deze regel zijn afgestudeerden van de sector Economie die doorgaans in een iets meer gemêleerd beroepenveld terecht komen. Dit zijn veelal beroepen in de private sector, waarvoor de gevolgen van de crisis door de overheidsmaatregelen met name op het gebied van afgenomen werkzekerheid liggen.

\section{Migratieachtergrond}

5,4\% van de afgestudeerden met een migratieachtergrond (d.w.z.: zelf buiten Nederland geboren of in Nederland geboren met tenminste één ouder die buiten Nederland is geboren) heeft sinds de coronacrisis zijn werk verloren. Ongeveer een derde van de werkende hbo'ers met een migratieachtergrond gaf bovendien aan een toename te ervaren in angst voor verlies van werk, en ongeveer een kwart gaf aan meer financiële problemen te ervaren dan voor de coronacrisis begon. Een minderheid (45\%) gaf aan vertrouwen te hebben in hoe de overheid omgaat met de crisis.

Opvallend is dat er weinig verschillen waren tussen de ervaringen van afgestudeerden met een westerse achtergrond en afgestudeerden met een niet-westerse achtergrond. Van de niet-westerse groep ervoer een relatief groter aandeel een sterke toename in stress, zowel op het werk (40\%) als thuis (39\%). Onder afgestudeerden met een westerse achtergrond gaven relatief meer respondenten aan sinds de crisis minder uren te zijn gaan werken (30\%).

\section{Maatschappelijke positie}

Een meerderheid van de afgestudeerden die als zelfstandige werken gaven aan tijdens de coronacrisis minder uren te werken dan voorheen (56\%). Een ruime meerderheid $(80 \%)$ van de zelfstandigen die minder uren zijn gaan werken hebben die uren niet doorbetaald gekregen, en $55 \%$ van de zelfstandigen die meer uren zijn gaan werken hebben de extra uren niet uitbetaald gekregen. Ook gaven zelfstandigen relatief vaak aan sinds de crisis meer angst te zijn gaan ervaren voor verlies van werk (56\%). Daarnaast geven zij aan financiële problemen te ervaren (43\%) en moeilijkheden te ondervinden bij het uitvoeren van hun werktaken (57\%). Een minderheid van de zelfstandigen (43\%) gaf aan vertrouwen te hebben in hoe de overheid omgaat met de coronacrisis. Tegelijkertijd hebben ze door de coronacrisis relatief vaak nieuwe ideeën opgedaan voor hun werk 
(51\%). Gelijkaardige ervaringen zien we ook - zij het meestal in iets mindere mate - bij afgestudeerden die zowel als zelfstandige als in loondienst werken. Deze laatste groep gaf bovendien in grote mate aan een toename in werkstress te ervaren (40\%) sinds het begin van de crisis.

Mensen die als maatschappelijke positie aangeven werkloos, student, of iets anders (dit houdt in: niet studerend, werkend of werkloos) te zijn, gaven aan sinds de coronacrisis een toename te ervaren in stress thuis (vooral studenten en werklozen: rond 50\%) en een toename te ondervinden in financiële problemen (vooral werklozen: $54 \%$ ). lets meer dan de helft van de werklozen (54\%) en mensen met een andere maatschappelijke positie (53\%) gaf aan vertrouwen te hebben in hoe de overheid omgaat met deze crisis.

\section{Groepen die niet of weinig afwijken van de totale populatie}

Tot slot is tussen sommige groepen juist opvallend weinig verschil te zien in de gevolgen van de coronacrisis voor hun leven en werk. Zo zijn er geen grote verschillen te zien tussen mannen en vrouwen, tussen verschillende leeftijdsgroepen en tussen afstudeercohorten (2015-2019). Deze laatste bevinding is zeker noemenswaardig, omdat vaak wordt aangenomen dat de coronacrisis vooral voor relatief recent afgestudeerde jongeren op de arbeidsmarkt nadelige gevolgen zou hebben. 


\section{Hbo'ers in tijden van corona}

\section{Inleiding}

Nederland kampt momenteel, net als de rest van de wereld, met de gevolgen van de COVID-19 crisis. Deze gevolgen - voor werken, voor studeren, voor huishoudens, en voor het sociale en culturele leven - zijn zeer vergaand, en veranderen dagelijks. Het Researchcentrum voor Onderwijs en Arbeidsmarkt heeft onlangs onderzoek gedaan naar de gevolgen van de coronacrisis voor de specifieke groep van hbo-afgestudeerden die tussen 2013 en 2018 zijn afgestudeerd. Dit onderzoek had als doel te onderzoeken hoe de coronacrisis van invloed is op de (arbeidsmarkt)positie, werkomstandigheden en het welbevinden van deze groep recent afgestudeerde hbo'ers. De maatregelen van de overheid om de verspreiding van het virus te voorkomen hebben een flinke impact op het dagelijkse leven. Het is nu al bekend dat vooral recent afgestudeerden bijzonder hard door deze maatregelen worden geraakt. Om de gevolgen van de crisis voor hboalumni in kaart te brengen richt dit onderzoek zich specifiek op deze doelgroep. Wat zijn de gevolgen van de coronacrisis voor hun arbeidsmarktpositie? Wat zijn de gevolgen van de crisis voor hun baanzekerheid, de kwaliteit van hun werk, hun dagelijkse werkzaamheden en hun eventuele vervolgstudie? En hoe voelen ze zich onder de huidige omstandigheden? Ervaren ze bijvoorbeeld meer stress dan voorheen? Maken ze zich zorgen over baanzekerheid? En hebben ze vertrouwen in de maatregelen die door de overheid zijn getroffen om met deze crisis om te gaan?

Met dit onderzoek hopen we van dienst te kunnen zijn voor beleidsmakers en andere stakeholders, die met de vraag worstelen hoe ze jonge hoogopgeleiden in het bijzonder het beste kunnen helpen in deze moeilijke periode. Door specifieke situaties van recent afgestudeerde hbo'ers die veel moeilijkheden ervaren in de huidige situatie in kaart te brengen, willen we materiaal bieden waarmee een gerichter beleid op basis van maatwerk voor deze specifieke doelgroepen mogelijk kan worden gemaakt. Dit rapport vat de belangrijkste resultaten samen van het onderzoek dat we hebben uitgevoerd tussen 7 mei en 8 juni 2020. Hierbij hebben we totaal 47.561 hbo-afgestudeerden benaderd die tussen 2013 en 2018 zijn afgestudeerd. Van de benaderde afgestudeerden, heeft 33,3\% de vragenlijst ingevuld en hun ervaringen gedurende de eerste maanden van de huidige crisis met ons gedeeld.

Dit rapport leest zich als volgt. Allereerst gaan we in hoofdstuk 2 in op de nadere details rondom de dataverzameling en de gevolgde onderzoeksmethodiek. In de hierop volgende hoofdstukken wordt vervolgens ingegaan op de gevolgen die de coronacrisis heeft gehad voor de maatschappelijke positie, de gewerkte uren en beloning, de ervaringen met thuiswerken, werktaken, materiële zorgen en stress- en gezond- 
heidsklachten van recent afgestudeerde hbo'ers. Hierna gaan we in op de gevolgen van de crisis voor de specifieke situaties van zelfstandigen, werklozen, studenten en hbo'ers met een andersoortige maatschappelijke positie. Voorts wordt een beschrijving gegeven van hoe hbo'ers aankijken tegen de aanpak van de overheid in deze crisis en hoe zij verwachten dat het met hen zal gaan na de crisis. We eindigen dit rapport met een algehele reflectie op de onderzoeksresultaten en een discussie van mogelijkheden voor vervolgonderzoek.

We gaan bij de beschrijving van de resultaten steeds eerst in op de ervaringen van de gehele onderzoekspopulatie. Daarna gaan we nader in op de ervaringen van deelpopulaties die relatief het sterkst afwijken in hun ervaringen ten opzichte van het populatiegemiddelde. Om precies te zijn, bespreken we de deelpopulaties met een significant en relevant ${ }^{3}$ hoger percentage op de betreffende uitkomst. We hebben ervoor gekozen om de tabellen zo kort en overzichtelijk mogelijk te houden, en om ervoor te zorgen dat de informatie waarop beleidsmakers en andere stakeholders zitten te wachten niet verloren gaat in een veelheid van andere data. ${ }^{4}$ Deze veelal negatieve uitkomsten zijn in het geheel niet bedoeld als reflectie op de getroffen doelgroepen. COVID-19 is immers een exogene force majeure die niet te voorzien was en waarvoor de gevolgen afhangen van zaken zoals de aard van werkzaamheden en de context waarin die worden uitgevoerd.

De hier gepresenteerde cijfers zijn puur beschrijvend van aard, en we maken geen claims in de richting van causaliteit. De cijfers zijn enkel bedoeld om aan te geven waar eventuele problemen zich wel of niet bevinden. Veel van de gepresenteerde deelpopulaties overlappen sterk met elkaar. Bijvoorbeeld, afgestudeerden van de hbo-sector Kunst werken vaak in artistieke beroepen en voeren hun werk in veel gevallen als zelfstandig ondernemer uit. Dit heeft als gevolg dat deze, deels overlappende deelpopulaties, vaak samen in tabellen verschijnen. Op een iets later moment willen we door middel van verdiepende analyses enig zicht krijgen op mogelijke oorzaken, waarbij de gevolgen van o.a. de opleidingssector, het beroep en de werkstatus uit elkaar worden gehaald.

Tenslotte: we zijn van plan om de situatie van de afgestudeerden die hebben deelgenomen aan dit onderzoek te blijven volgen, zodat meer zicht kan worden verkregen op de mate waarin ervaren moeilijkheden worden hersteld naarmate de door de overheid getroffen maatregelen meer en meer versoepeld worden. De in dit rapport gepresenteerde resultaten hebben dus puur betrekking op de ervaringen van jonge hbo-afgestudeerden gedurende de eerste paar maanden van de coronacrisis.

3 Significantie wordt op 1\%-niveau bepaald door gebruik van een tweezijdige 1-proportie z-toets. Dit is een conservatieve toets, maar omdat we over een groot aantal observaties beschikken, kunnen zelfs bij deze conservatieve toetsing soms kleine verschillen al significant zijn. Om ons ervan te verzekeren dat de getoonde verschillen betekenisvol zijn, is naast significantie een tweede eis van relevantie gesteld. Een verschil werd als relevant aangemerkt wanneer het genormaliseerde verschil tussen het groepscijfer en het landelijke cijfer meer dan 10\% van het landelijke cijfer bedraagt. Zo worden bijvoorbeeld bij een populatieaandeel van $50 \%$, enkel subgroepen in de tabellen getoond met een aandeel van $55 \%$ of hoger.

4 De volledige tabellen, inclusief uitkomsten voor groepen die veel minder zwaar zijn getroffen, staan ook de HBO-Monitor website www.hbomonitor.nl. 


\section{Data en methoden}

Dit onderzoek is uitgevoerd onder hbo-afgestudeerden die in de afgelopen vijf jaar hebben deelgenomen aan de HBO-Monitor ${ }^{5}$ of de Kunsten-Monitor ${ }^{6}$ en die zich middels deze onderzoeken bereid hebben getoond om aan vervolgonderzoek mee te doen. Dit betreft afgestudeerden uit afstudeercohorten 2013-2014, 2014-2015, 2015-2016, 20162017 en 2017-2018. Deze groep afgestudeerden heeft een valide emailadres opgegeven waarmee ze voor dit onderzoek te bereiken waren. Na het opschonen van beide contactbestanden hielden we in totaal 47.561 emailadressen over, waarvan 44.459 van afgestudeerden van de $\mathrm{HBO}-$ Monitor en 3.102 van afgestudeerden van de Kunsten-Monitor.

De online vragenlijsten zijn ontwikkeld met gebruik van Qualtrics-software. Er zijn twee aparte vragenlijsten ontworpen: een voor afgestudeerden van de hbo-sectoren Agro\&Food, Bètatechniek, Economie, Gezondheidszorg, Onderwijs en Sociale Studies en een aparte vragenlijst voor de sector Kunst. Beide vragenlijsten delen in grote mate een gemeenschappelijke kern, waardoor over nagenoeg alle uitkomsten integraal rapportage uitgebracht kon worden. Het belangrijkste verschil tussen de twee vragenlijsten ${ }^{7}$ was dat bij de vragenlijst voor de kunstsector bij een aantal zaken een onderscheid werd aangebracht tussen werken binnen en/of buiten het eigen vakgebied. In de praktijk bleken de meeste respondenten minder dan 10 minuten nodig te hebben om de volledige vragenlijst in te vullen.

De eerste uitnodigingsmails voor deelname aan de vragenlijst voor de afgestudeerden van de hbo-sectoren Agro\&Food, Bètatechniek, Economie, Gezondheidszorg, Onderwijs en Sociale Studies zijn uitgezonden op 7 mei van dit jaar. In totaal zijn in de daaropvolgende 4 weken drie rappelmails gestuurd. Het veldwerk werd gesloten op 6 juni, op welk moment 14.395 afgestudeerden hadden gerespondeerd, overeenkomstig met een responspercentage van $32,4 \%$. Omdat de vragenlijst voor de afgestudeerden van de kunstsector later klaar voor verzending was, is het veldwerk hiervoor pas op 20 mei van start gegaan. Ondanks deze latere start, is voor deze groep - na drie rappels - op 8 juni het veldwerk afgesloten met een responsaantal van 1.420 deelnemers en een responspercentage van $45,8 \%$. In totaal hebben 15.815 respondenten meegedaan aan beide onderzoeken, overeenkomstig met een gecombineerd responspercentage van $33,3 \%$.

In dit rapport wordt verslag gedaan van de antwoorden van respondenten op een aantal stellingen die hen middels de enquête werden voorgelegd. Deze stellingen kunnen in grofweg drie categorieën worden ingedeeld. Allereerst werden respondenten gevraagd hun ervaringen te beschrijven van (a) vóór de coronacrisis (namelijk op 31 januari 2020)

5 De HBO-Monitor is een jaarlijks onderzoek onder alle afgestudeerde hbo'ers. Het geeft inzicht in de ervaringen van afgestudeerden op de arbeidsmarkt gedurende de eerste anderhalf jaar nadat zij zijn afgestudeerd.

6 De Kunsten-Monitor is een variant van de HBO-Monitor die specifiek is ontwikkeld voor afgestudeerden van hbo-kunstopleidingen, omdat de arbeidsmarktloopbaan van deze groep hbo'ers er doorgaans ietwat anders uitziet dan die van andere hbo'ers. Zo werken kunsten-afgestudeerden bijvoorbeeld relatief vaak in meerdere banen zowel binnen als buiten hun vakgebied en werken zij vaker als zelfstandige. De vragenlijsten zijn te vinden op www.hbomonitor.nl. 
en (b) gedurende de coronacrisis (moment van enquêtering). Daarna werden respondenten gevraagd voor iedere stelling aan te geven in welke mate zij hierin een verandering ervaarden ten opzichte van voor de crisis. Respondenten werden verzocht middels een 11-puntenschaal ( $\mathrm{ot} / \mathrm{m} 10$ ) aan te geven in hoeverre ze het eens waren met de betreffende stelling. Bij antwoorden $\geq 6$ op een stelling werd ervan uitgegaan dat respondenten het (enigszins) eens waren met de stelling. Bij de vragen over ervaren verandering sinds de crisis werden respondenten gevraagd middels een 11-puntenschaal lopende van $-5 \mathrm{t} / \mathrm{m} 5$ aan te geven of deze ervaring in negatieve zin, in positieve zin of niet was veranderd ten gevolge van de crisis. Bij antwoorden $\geq 2$ of $\leq-2$ op de tweede vraag, werd uitgegaan van een respectievelijke toe- of afname in deze aspecten. Het bepalen van statistische significantie van verschillen tussen subgroepen werd op 1\%-niveau bepaald door gebruik van een 1-proportie z-toets. Een verschil werd als relevant aangemerkt wanneer het genormaliseerde verschil tussen de subgroepsproportie en de gehele populatie meer dan 10\% bedroeg. Zo worden bijvoorbeeld bij een populatieaandeel van 50\%, enkel subgroepen in de tabellen getoond met een aandeel van $55 \%$ of hoger.

\section{Verandering in maatschappelijke positie}

De overheidsmaatregelen ter bestrijding van de corona-epidemie hebben grote gevolgen gehad voor de Nederlandse economie en samenleving, onder andere op het gebied van werken en leren. Tabel 1 geeft een eerste indruk van de gevolgen van de coronacrisis voor recente cohorten hbo-afgestudeerden. Deze tabel toont de maatschappelijke positie van hbo-afgestudeerden vóór het begin van de epidemie in dit land (retrospectief gevraagd naar situatie op 31 januari 2020) en op het moment van de enquête (tussen 7 mei en 8 juni 2020). Uit Tabel 1 blijkt dat de werkloosheid ${ }^{8}$ in de tussenliggende periode meer dan verdubbeld is. Dit percentage was echter op 31 januari 2020 met 2,2\% zeer laag, waardoor in absolute termen de huidige werkloosheid met $4,6 \%$ vooralsnog redelijk binnen de perken is gebleven. Interessant is de bevinding dat de werkgelegenheid enkel onder hbo'ers die uitsluitend in loondienst werken is gekrompen. Het percentage afgestudeerden dat voor zichzelf werkt - al dan niet in combinatie met werk in loondienst - is nagenoeg gelijk gebleven. Het aandeel afgestudeerden dat na hun hbo-opleiding verder is gaan studeren is tot slot licht gedaald, maar dit hoeft niet per se het gevolg te zijn van de corona-restricties. Mogelijk heeft een deel van deze groep gedurende de intelligente lockdown hun diploma behaald.

8 Deze subjectieve meting van werkloosheid is niet direct vergelijkbaar met het officiële werkloosheidscijfer zoals dat door het Centraal Bureau voor de Statistiek (CBS) volgens de definitie van de International Labour Organization (ILO) wordt berekend, maar geeft wel een indicatie van de veranderingen die hebben plaatsgevonden. Anders dan in de CBS-definitie wordt hier geen rekening gehouden met de vraag of men actief op zoek is naar werk en snel beschikbaar is als werk wordt aangeboden. 
Tabel 1. Maatschappelijke positie vóór en tijdens coronacrisis

\begin{tabular}{|l|r|r|}
\hline & $\begin{array}{r}\text { Maatschappelijke positie direct } \\
\text { vóór coronacrisis (31 jan. jl) }\end{array}$ & $\begin{array}{r}\text { Maatschapelijke positie } \\
\text { tijdens coronacrisis }\end{array}$ \\
\hline In loondienst & $78,7 \%$ & $76,5 \%$ \\
\hline Zelfstandige, zzp'er of freelancer & $6,9 \%$ & $7,0 \%$ \\
\hline Zowel in loondienst als zelfstandige & $4,8 \%$ & $4,9 \%$ \\
\hline Student & $5,5 \%$ & $5,1 \%$ \\
\hline Werkloos & $2,2 \%$ & $4,6 \%$ \\
\hline Anders & $1,9 \%$ & $1,9 \%$ \\
\hline & & 15812 \\
\hline
\end{tabular}

Wanneer we specifiek naar de groep afgestudeerden kijken die op 31 januari 2020 betaald werk verrichtte, blijkt dat 3,1\% hiervan op het moment van enquêtering (drie tot vier maanden later) werkloos was (niet in Tabel 1 vermeld). Dit verlies van werk is niet homogeen over de verschillende subgroepen van afgestudeerden verdeeld, zoals uit Tabel 2 blijkt. Tabel 2 toont de groepen die een significant en relevant sterkere toename in werkloosheid vertoonden dan de populatie als geheel. De grootste toename is te zien voor afgestudeerden die afkomstig zijn uit de sector Kunst. Deze toename is waarschijnlijk grotendeels toe te schrijven aan de beroepen waarin men op 31 januari 2020 werkzaam is, maar deze informatie zit niet in de dataset. Afgestudeerden van de sector Economie hebben ook vaker dan gemiddeld hun baan verloren sinds 31 januari 2020, evenals afgestudeerden met een westerse of niet-westerse migratieachtergrond.

Tabel 2. Subgroepen hbo'ers met een relatief sterke toename van werkloosheid vanaf 31 januari 2020 (gemiddeld 3,1\%)

\begin{tabular}{|c|c|}
\hline \multicolumn{2}{|c|}{ Relatief sterke toename in werkloosheid } \\
\hline \multicolumn{2}{|c|}{ Hbo-sector } \\
\hline Economie & $4,0 \%$ \\
\hline Kunst & $10,4 \%$ \\
\hline \multicolumn{2}{|l|}{ Leeftijd } \\
\hline \multicolumn{2}{|c|}{ Migratieachtergrond } \\
\hline Niet-westers & $5,0 \%$ \\
\hline Westers & $5,8 \%$ \\
\hline
\end{tabular}

\section{Verandering in aantal gewerkte uren en beloning}

Uit Tabel 3 blijkt dat hbo'ers op moment van enquêtering gemiddeld iets minder uren werkten dan voor de coronacrisis (31 januari 2020). Achter deze relatief kleine verandering gaan echter voor veel afgestudeerden enkele grotere veranderingen schuil. Zo is sinds de coronacrisis bijna een kwart van de werkende hbo'ers minder gaan werken, en werkte één op de vijf werkenden in dezelfde periode juist meer. 
Tabel 3. Gemiddeld aantal uren gewerkt vóór corona en op moment van enquêtering

\begin{tabular}{|c|c|}
\hline \multicolumn{2}{|l|}{ Gewerkte uren (gem.) } \\
\hline Vóór corona & 36,5 \\
\hline Tijdens corona & 35,3 \\
\hline \multicolumn{2}{|c|}{ Verandering in gewerkte uren (\%) } \\
\hline Werkt minder uren & $23,4 \%$ \\
\hline Werkt meer uren & $19,8 \%$ \\
\hline
\end{tabular}

Tabel 4 laat zien hoe dit verschillend uitpakt voor diverse subgroepen. Deze tabel toont de groepen die significant vaker minder of meer uren zijn gaan werken ten tijde van de coronacrisis. Uit deze tabel blijkt allereerst dat bijna de helft van de werkenden in artistieke beroepen minder uren is gaan werken. Bijna een derde van de werkenden in onderwijskundige beroepen is meer uren gaan werken, terwijl een iets kleiner (maar nog altijd bovengemiddeld) aandeel in dezelfde periode minder is gaan werken. De veranderingen voor de hbo-sectoren Kunst en Onderwijs liggen vrijwel zeker aan het feit dat ze overwegend in respectievelijk artistieke en onderwijskundige beroepen werkzaam zijn. Opvallend is dat veel hbo'ers die voor de coronacrisis als zelfstandige werkten, gedurende de crisis minder uren zijn gaan werken. Het behoud van werk voor deze groep is dus gepaard gegaan met inlevering van werkuren. Uit de tabel blijkt verder dat hbo'ers met een westerse migratieachtergrond relatief vaak minder uren zijn gaan werken.

Tabel 4. Subgroepen hbo'ers die relatief minder of meer uren zijn gaan werken gedurende de coronacrisis

\begin{tabular}{|l|r|r|r|r|}
\hline & Werkt minder uren & Werkt meer uren \\
\hline Beroep & Artistiek & $48,1 \%$ & & \\
\hline & Dienstverlenend & $39,4 \%$ & & \\
\hline Onderwijskundig & $28,3 \%$ & Onderwijskundig & $32,6 \%$ \\
\hline Lbo-sector & Kunst & $48,6 \%$ & Onderwijs & $32,1 \%$ \\
\hline Leeftijd & & & 40 jaar of ouder & $27,4 \%$ \\
\hline Migratieachtergrond & Westers & $30,4 \%$ & & \\
\hline Pre-corona status & Combinatie van loondienst & & & \\
\hline & én zelfstandig & $40,6 \%$ & & \\
\hline
\end{tabular}

Een belangrijke vraag hierbij is welke gevolgen deze veranderingen hebben gehad voor de inkomens van afgestudeerden. Omdat de enquête kort en laagdrempelig moest zijn, hebben we geen gedetailleerde inkomensvragen gesteld. Wel hebben we respondenten gevraagd in grote lijnen aan te geven welke gevolgen de coronacrisis heeft gehad voor hun inkomenspositie in relatie tot de (mogelijke) verandering in hun werkuren. Meer specifiek hebben we aan mensen die meer uren zijn gaan werken gevraagd of ze die uren uitbetaald krijgen, aan mensen die minder zijn gaan werken of ze de verminderde 
uren doorbetaald krijgen, en aan mensen waarvoor de werkuren nagenoeg gelijk zijn gebleven of ze nog altijd betaald worden voor hun gewerkte uren.

Tabel 5 toont de resultaten. Van de hbo'ers die gedurende de coronacrisis extra uren zijn gaan werken, krijgt ongeveer een op de vijf deze uren volledig uitbetaald. $8 \%$ krijgt enkel een deel van de uren uitbetaald, en ongeveer 30\% mag op een later moment ter compensatie van de overuren minder werken. Bijna $45 \%$ krijgt geen enkele compensatie voor de extra gewerkte uren. De andere kant van de medaille is dat de meerderheid van de hbo'ers die gedurende de coronacrisis minder uren is gaan werken in veel gevallen deels, maar meestal volledig, kreeg doorbetaald. lets minder dan een kwart kreeg de verloren uren niet doorbetaald. Tenslotte is aan hbo'ers waarvoor de werkuren niet zijn veranderd gevraagd of ze deze uren nog altijd uitbetaald krijgen. Vrijwel alle afgestudeerden die gelijke uren zijn blijven werken krijgen nog altijd de volledige beloning hiervoor. Wel levert 3,4\% een deel van het loon in, en 2,1\% zelfs het volledige loon. Hoewel deze groep zeer klein is, brengt deze groep dus een behoorlijk groot offer gedurende deze crisis.

Tabel 5. Gevolgen van de coronacrisis voor de inkomenspositie van afgestudeerden

\begin{tabular}{|l|r|r|r|}
\hline Antwoorden op vraag: in welke mate krijg & $\begin{array}{r}\text { Extra uren } \\
\text { uitbetaald }\end{array}$ & $\begin{array}{r}\text { Verminderde } \\
\text { uren doorbetaald }\end{array}$ & $\begin{array}{r}\text { Gelijke uren } \\
\text { uitbetaald }\end{array}$ \\
\hline ja, helemual & $18,9 \%$ & $56,9 \%$ & $94,6 \%$ \\
\hline Ja, deels & $7,6 \%$ & $13,2 \%$ & $3,4 \%$ \\
\hline Nee, maar ik mag deze uren naderhand compenseren & $28,9 \%$ & - & - \\
\hline Nee, niet uitbetaald & $44,6 \%$ & $29,9 \%$ & $2,1 \%$ \\
\hline
\end{tabular}

Tabel 6 toont tot slot de groepen die relatief gezien de grootste offers hebben gebracht in termen van hun inkomens. Uit deze tabel blijkt dat werkenden in artistieke beroepen en afgestudeerden die als zelfstandige werken, op alle fronten meer dan gemiddeld hebben ingeleverd in termen van inkomen. Ze worden vaker niet gecompenseerd voor extra gewerkte uren, krijgen minder vaak gewerkte uren doorbetaald, en worden vaker bij gelijke uren gekort op een deel van hun inkomen. Hiernaast blijken werkenden in onderwijskundige beroepen relatief vaak extra te werken zonder betaling. De beloning van afgestudeerden van de hbo-sectoren Kunst en Onderwijs zijn in lijn met die van de beroepen waarin ze het vaakst werken. 
Tabel 6. Subgroepen hbo'ers die relatief vaak minder zijn gecompenseerd voor gewerkte en/ of niet-gewerkte uren

\begin{tabular}{|c|c|c|c|c|c|}
\hline \multicolumn{2}{|l|}{$\begin{array}{l}\text { Niet gecompenseerd } \\
\text { voor extra uren }\end{array}$} & \multicolumn{2}{|c|}{$\begin{array}{l}\text { Krijgt verminderde uren } \\
\text { niet doorbetaald }\end{array}$} & \multicolumn{2}{|l|}{$\begin{array}{l}\text { Levert salaris in } \\
\text { bij gelijke uren }\end{array}$} \\
\hline \multicolumn{6}{|l|}{ Beroep } \\
\hline \multirow[t]{2}{*}{ Artistiek } & $55,1 \%$ & Artistiek & $67,9 \%$ & Artistiek & $32,2 \%$ \\
\hline & & & & Dienstverlenend & $6,4 \%$ \\
\hline Onderwijskundig & $85,7 \%$ & & & Onderwijskundig & $6,9 \%$ \\
\hline \multicolumn{6}{|l|}{ Hbo-sector } \\
\hline Kunst & $59,6 \%$ & Kunst en cultuur & $60,7 \%$ & Kunst & $26,9 \%$ \\
\hline Onderwijs & $14,3 \%$ & & & Onderwijs & $7,5 \%$ \\
\hline \multicolumn{6}{|l|}{ Leeftijd } \\
\hline 40 jaar of ouder & $62,0 \%$ & & & & $6,6 \%$ \\
\hline \multicolumn{6}{|l|}{ Cohort } \\
\hline Meetjaar 2016 & $49,9 \%$ & & & Meetjaar 2015 & $6,4 \%$ \\
\hline \multicolumn{6}{|l|}{ Migratieachtergrond } \\
\hline & & & & Niet-westers & $7,3 \%$ \\
\hline & & & & Westers & $8,7 \%$ \\
\hline \multicolumn{6}{|l|}{ Pre-corona status } \\
\hline Loondienst én zelfstandig & $50,0 \%$ & $\begin{array}{l}\text { Loondienst én } \\
\text { zelfstandig }\end{array}$ & $49,1 \%$ & $\begin{array}{l}\text { Loondienst én } \\
\text { zelfstandig }\end{array}$ & $13,8 \%$ \\
\hline Zelfstandig & $54,9 \%$ & Zelfstandig & $80,4 \%$ & Zelfstandig & $38,1 \%$ \\
\hline
\end{tabular}

\section{Thuiswerken}

Een van de meest zichtbare gevolgen van de coronacrisis is dat meer mensen noodgedwongen thuis zijn gaan werken. Uit Tabel 7 blijkt dat dit ook voor veel hbo'ers geldt. Zo'n $42 \%$ werkte op moment van enquêtering uitsluitend thuis, en bijna 31\% werkte deels thuis. Slechts $27 \%$ werkte alleen buitenshuis. Natuurlijk werken ook in "normale" tijden sommige mensen thuis, maar we hebben hiervan geen pre-coronameting om dit te checken. We kunnen deze percentages dus niet zonder meer aan de coronacrisis toeschrijven. Het is echter aannemelijk dat thuiswerken vóór de coronacrisis eerder uitzondering dan regel was.

Tabel 7. Huidige werklocatie

\begin{tabular}{|c|c|}
\hline Waar werk je momenteel? & \\
\hline Thuis & $42,3 \%$ \\
\hline Op één of meerdere externe locaties & $26,9 \%$ \\
\hline Soms thuis, soms extern & $30,8 \%$ \\
\hline
\end{tabular}

Tabel 8 laat verder zien welke subgroepen hbo'ers op moment van enquêtering relatief vaak thuiswerkten. Veel van de resultaten die deze tabel toont liggen behoorlijk voor de 
hand. Zo werkten hbo'ers die werkzaam zijn in beroepen waarin werk wordt verricht dat in principe op iedere locatie kan worden uitgevoerd met name veel thuis. Dat mannen en hbo'ers met een niet-westerse migratieachtergrond relatief ook veel thuis werkten, heeft vermoedelijk ook te maken met het feit dat deze subgroepen relatief weinig in zorgberoepen werken. Nader onderzoek moet uitwijzen of er een resterend effect hiervan overblijft wanneer voor beroep is gecontroleerd.

Tabel 8. Subgroepen hbo'ers die voornamelijk thuis werken

\begin{tabular}{|c|c|}
\hline \multicolumn{2}{|l|}{ Werkt relatief voornamelijk thuis } \\
\hline \multicolumn{2}{|l|}{ Beroep } \\
\hline Administratief, adviserend of management & $53,8 \%$ \\
\hline Artistiek & $51,8 \%$ \\
\hline Commercieel of zakelijk & $60,6 \%$ \\
\hline \multicolumn{2}{|l|}{ Geslacht } \\
\hline Man & $47,4 \%$ \\
\hline \multicolumn{2}{|l|}{ Hbo-sector } \\
\hline Economie & $58,6 \%$ \\
\hline Kunst & $47,8 \%$ \\
\hline Bètatechniek & $49,1 \%$ \\
\hline \multicolumn{2}{|l|}{ Migratieachtergrond } \\
\hline Niet-westers & $50,7 \%$ \\
\hline
\end{tabular}

\section{Materiële zorgen}

Er is veel te doen geweest over de gevolgen van de coronacrisis voor het vertrouwen van burgers in hun materiele welvaart en toekomst. Om te zien in hoeverre zulke zorgen onder recent-afgestudeerde cohorten hbo'ers leven, hebben we aan hen gevraagd in hoeverre zij gevoelens van angst voor het verliezen van hun baan of financiële problemen ervaren, en in hoeverre deze gevoelens veranderd zijn ten gevolge van de crisis. In Tabel 9 is weergeven welk deel van de respondenten dergelijke angstgevoelens of financiële problematiek ervaart, evenals het deel dat aangeeft dat dergelijke angstgevoelens of financiële problemen gedurende de coronacrisis toe- of afgenomen zijn. Echter, het aandeel afgestudeerden dat in angst leeft voor het mogelijk verlies van hun werk, en het aandeel afgestudeerden dat financiële problemen ervaart is vooralsnog betrekkelijk klein. Op beide fronten is echter wel sprake van een duidelijke toename ten gevolge van de crisis: bijna een kwart van de afgestudeerden gaf aan op moment van enquêtering nerveuzer over hun werkzekerheid te zijn dan voor de coronacrisis en ongeveer één op de zeven gaf aan een toename in financiële problemen te ervaren. Een kleiner deel gaf aan juist minder angst of problemen op deze gebieden te ervaren in coronatijd, terwijl de rest - zo'n 70\% in het geval van angst voor het verlies van werk, en ruim $80 \%$ in het geval van financiële problemen - geen noemenswaardige veranderingen ervoer. 
Tabel 9. Angst voor verlies van werk en financiële problemen op moment van enquêtering, en mate waarin angst is toe- of afgenomen ten gevolge van de coronacrisis

\begin{tabular}{|l|r|r|r|}
\hline & $\begin{array}{r}\text { In sterke mate van sprake } \\
\text { tijdens enquêtering }\end{array}$ & $\begin{array}{r}\text { Dit is tijdens coronacrisis } \\
\text { toegenomen }\end{array}$ & $\begin{array}{r}\text { Dit is tijdens coronacrisis } \\
\text { afgenomen }\end{array}$ \\
\hline Angst voor verlies van werk & $10,0 \%$ & $23,3 \%$ & $6,4 \%$ \\
\hline Financiële problemen & $7,0 \%$ & $13,9 \%$ & $4,4 \%$ \\
\hline
\end{tabular}

Tabel 10 laat zien bij welke subgroepen hbo'ers sprake is van een bovengemiddelde toename in angst voor het verlies van werk. Veel hbo'ers die werkzaam zijn in beroepen waarin producten en/of diensten tegen betaling op de vrije markt worden aangeboden en hbo'ers die afgestudeerd zijn in sectoren waarin men doorgaans voor dergelijke beroepen is opgeleid, zijn bovengemiddeld pessimistischer geworden over hun werkzekerheid tijdens de coronacrisis. Zelfstandigen (al dan niet in combinatie met loondienst) zijn hier op moment van bevraging ook veel angstiger voor dan voor de crisis, ondanks het feit dat ze tot nu toe relatief minder vaak werkloos zijn geraakt ten gevolge van de crisis dan andere maatschappelijke groepen (zie Tabel 2). Verder zien we een toenemende mate van pessimisme op dit punt onder hbo'ers met een migratieachtergrond, zowel westers als niet-westers.

Tabel 10. Subgroepen hbo'ers waarbij sprake is van een relatief sterke toename in angst voor verlies van werk tijdens de coronacrisis

\begin{tabular}{|c|c|}
\hline \multicolumn{2}{|l|}{ Toename in angst voor verlies van werk } \\
\hline \multicolumn{2}{|l|}{ Beroep } \\
\hline Artistiek & $57,8 \%$ \\
\hline Commercieel of zakelijk & $31,4 \%$ \\
\hline Dienstverlenend & $46,7 \%$ \\
\hline Overig (incl. agrarisch) & $27,5 \%$ \\
\hline \multicolumn{2}{|l|}{ Hbo-sector } \\
\hline Economie & $29,8 \%$ \\
\hline Kunst & $53,5 \%$ \\
\hline \multicolumn{2}{|l|}{ Huidige status } \\
\hline Combinatie van loondienst én zelfstandig & $38,8 \%$ \\
\hline Zelfstandig & $55,9 \%$ \\
\hline \multicolumn{2}{|l|}{ Migratieachtergrond } \\
\hline Niet-westers & $28,4 \%$ \\
\hline Westers & $33,9 \%$ \\
\hline
\end{tabular}

In Tabel 11 staan de subgroepen vermeld waarbij sprake is van een bovengemiddelde toename op het gebied van financiële problemen. Financiële problemen lijken vooral toegenomen onder hbo'ers werkzaam in artistieke en dienstverlenende beroepen, hbo'ers die afgestudeerd zijn in de kunstsector (die vaak in artistieke beroepen werken), en werkloze, zelfstandige en studerende hbo'ers. Tevens meer financiële problemen - zij het in iets mindere mate- worden ervaren door afgestudeerden met een westerse of 
niet-westerse migratieachtergrond, en relatief recent afgestudeerden (namelijk afgestudeerden uit meetjaar 2019, het meest recente cohort).

Tabel 11. Subgroepen hbo'ers waarbij sprake is van een relatief sterke toename in ervaren financiële problemen

\begin{tabular}{|c|c|}
\hline Toename in financiële problemen & \\
\hline \multicolumn{2}{|l|}{ Beroep } \\
\hline Artistiek & $38,6 \%$ \\
\hline Dienstverlenend & $21,5 \%$ \\
\hline \multicolumn{2}{|l|}{ Hbo-sector } \\
\hline Kunst & $42,7 \%$ \\
\hline \multicolumn{2}{|l|}{ Cohort } \\
\hline Meetjaar 2019 & $16,3 \%$ \\
\hline \multicolumn{2}{|l|}{ Migatieachtergrond } \\
\hline Niet-westers & $20,8 \%$ \\
\hline Westers & $25,5 \%$ \\
\hline \multicolumn{2}{|l|}{ Huidige status } \\
\hline Anders & $17,9 \%$ \\
\hline Combinatie van loondienst én zelfstandig & $26,7 \%$ \\
\hline Student & $33,6 \%$ \\
\hline Werkloos & $52,7 \%$ \\
\hline Zelfstandig & $43,4 \%$ \\
\hline
\end{tabular}

\section{Uitvoering van werktaken}

Een groot deel van de economische problemen die de coronacrisis heeft veroorzaakt, vloeit voort uit het feit dat veel werkzaamheden moeilijker zijn geworden om uit te voeren met inachtneming van de 'social distancing' regels. Tegelijkertijd wordt soms geponeerd dat deze moeilijkheden juist een drijfveer zouden vormen voor mensen om creatief te zijn in hun werk, en om nieuwe wekwijzen te vinden waarmee ondanks de restricties toch nog redelijk goed kan worden gewerkt. Om hier meer zicht op te krijgen hebben we aan de respondenten de volgende twee stellingen voorgelegd: (1) door de coronacrisis is het moeilijker geworden mijn werktaken te verrichten, en (2) door de coronacrisis heb ik nieuwe ideeën opgedaan voor mijn werk. In Tabel 12 staat het aandeel respondenten dat het enigszins tot helemaal eens is met deze stellingen. Dit blijkt in beide gevallen iets minder dan de helft te zijn.

Tabel 12. Aandeel hbo'ers dat aangeeft dat het door de coronacrisis moeilijker is geworden om werktaken te verrichten, en/of tijdens de coronacrisis nieuwe ideeën heeft opgedaan

\begin{tabular}{lr} 
Door de coronacrisis is het moeilijker geworden mijn werktaken te verrichten & $\begin{array}{r}\% \text { enigszins tot } \\
\text { helemaal eens }\end{array}$ \\
Door de coronacrisis heb ik nieuwe ideeën opgedaan voor mijn werk & $46,6 \%$ \\
\hline
\end{tabular}


Tabel 13. Subgroepen hbo'ers die aangeven dat het door de coronacrisis moeilijker voor hen is geworden om werktaken te verrichten, en/of tijdens de coronacrisis nieuwe ideeën heeft opgedaan

\begin{tabular}{|c|c|c|c|c|}
\hline \multirow[b]{2}{*}{ Beroep } & \multicolumn{2}{|c|}{$\begin{array}{r}\text { Door corona is het moeilijker geworden } \\
\text { mijn werktaken te verrichten }\end{array}$} & \multicolumn{2}{|c|}{$\begin{array}{r}\text { Door corona heb ik nieuwe ideeën } \\
\text { opgedaan voor mijn werk }\end{array}$} \\
\hline & Artistiek & $55,2 \%$ & Onderwijskundig & $72,5 \%$ \\
\hline & Hulpverlenend & $63,3 \%$ & & \\
\hline & Onderwijskundig & $60,9 \%$ & & \\
\hline & Gezondheidszorg & $51,7 \%$ & & \\
\hline \multirow[t]{3}{*}{ Hbo-sector } & Sociale studies & $57,9 \%$ & Kunst & $53,1 \%$ \\
\hline & Kunst & $59,1 \%$ & Onderwijs & $72,1 \%$ \\
\hline & Onderwijs & $59,7 \%$ & & \\
\hline Leeftijd & & & 40 jaar of ouder & $62,1 \%$ \\
\hline \multirow[t]{2}{*}{ Huidige status } & Loondienst én zelfstandig & $51,6 \%$ & Loondienst én zelfstandig & $54,6 \%$ \\
\hline & Zelfstandig & $57,3 \%$ & & \\
\hline Huidige werklocatie & Soms thuis, soms buitenshuis & $52,7 \%$ & Soms thuis, soms buitenshuis & $51,3 \%$ \\
\hline
\end{tabular}

In Tabel 13 is vermeld welke subgroepen hbo'ers het bovengemiddeld vaak eens zijn met deze stellingen. In sommige gevallen komen dezelfde subgroepen voor aan beide kanten van Tabel 13. Zo geven hbo'ers die werkzaam zijn in onderwijskundige beroepen, afgestudeerden van de sectoren Onderwijs en Kunst en afgestudeerden die soms thuis en soms buitenshuis werken, relatief vaak tegelijkertijd aan dat hun werktaken door de coronacrisis moeilijker te verrichten zijn én dat ze door de coronacrisis tot nieuwe ideeën zijn geïnspireerd. Het valt buiten het bereik van dit rapport om harde uitspraken te doen over een causale relatie tussen deze twee simultane ontwikkelingen, maar het behoort zeker tot de mogelijkheden dat het een tot het ander leidt. Uit onderzoek is immers bekend dat ingewikkelde denkprocessen voedzaam zijn voor creativiteit. ${ }^{9}$ We zien echter ook een aantal uitzonderingen op deze algemene regel. Zo geven hbo'ers werkzaam in artistieke, hulpverlenende en gezondheidszorgberoepen, afgestudeerden van de sector Sociale Studies en afgestudeerden die uitsluitend als zelfstandige werken, vaker dan gemiddeld aan dat hun werktaken moeilijker zijn geworden, zonder dat ze hierdoor tot een bovengemiddelde mate van creativiteit zijn gedreven. Aan de andere kant zien we dat mensen die zowel in loondienst als als zelfstandige werken alsook relatief oudere afgestudeerden relatief vaak tot nieuwe ideeën zijn gekomen, zonder een corresponderende toename in de moeilijkheid van hun werktaken.

\section{Gezondheid en stress}

Tabel 14 geeft de huidige toestand van hbo'ers weer in termen van gezondheid en stress. Daarnaast geeft deze tabel inzicht in het aandeel afgestudeerden dat aangaf dat

9 Zie bijvoorbeeld: Binyamin, G., \& Carmeli, A. (2017). Fostering members' creativity in teams: The role of structuring of human resource management processes. Psychology of Aesthetics, Creativity, and the Arts, 11, 18. 
problemen op deze twee gebieden toe- of afgenomen zijn gedurende de coronacrisis. Uit de tabel blijkt dat twee derde van de afgestudeerden op moment van bevraging in goede gezondheid verkeerde, en dat dit voor slechts één op de vijf oud-studenten is veranderd ten gevolge van de coronacrisis. Hierbij is opvallend dat meer afgestudeerden van mening zijn dat hun gezondheidssituatie is verbeterd in coronatijd dan dat dit achteruit is gegaan. Dit ligt duidelijk anders bij stress, zowel thuis als op het werk. Ongeveer een kwart van de respondenten gaf aan dat ze op moment van bevraging stress ervoeren op het werk, en ongeveer $14 \%$ gaf aan dat er sprake was van stress thuis. Bij beide stressmaten is sprake van een duidelijke toename gedurende de coronacrisis (ongeveer een derde gaf dit aan), terwijl minder dan één op de tien aangaf op moment van bevraging minder stress te ervaren.

Tabel 14. Huidige situatie en veranderingen door corona: gezondheid en stress

\begin{tabular}{|l|l|l|l|} 
& $\begin{array}{l}\text { Huidige situatie } \\
\text { Geldt in sterke mate }\end{array}$ & $\begin{array}{l}\text { Verandering } \\
\text { Toename }\end{array}$ & Afname \\
\hline Goede gezondheid & $67,2 \%$ & $12,4 \%$ & $7,9 \%$ \\
\hline Stress bij werk & $24,8 \%$ & $34,2 \%$ & $8,6 \%$ \\
\hline Stress thuis & $14,3 \%$ & $31,5 \%$ & $6,0 \%$
\end{tabular}

Tabel 15 laat verder zien voor welke subgroepen hbo'ers sprake is van een relatief sterkere afname in de gezondheidssituatie ten opzichte van het landelijk gemiddelde. Wat als eerste opvalt is dat zelfs in het minst gunstige geval nog geen $15 \%$ van de respondenten aangeeft dat hun gezondheid in deze periode achteruit is gegaan. Hbo'ers uit de kunstsector, iets oudere respondenten, hbo'ers met een westerse of niet-westerse migratieachtergrond, studenten, werklozen en hbo'ers die aangaven niet werkzaam, werkloos, of studerend te zijn (anders) gaven wel vaker dan gemiddeld aan dat hun gezondheid achteruit is gegaan gedurende de crisis.

Tabel 15. Subgroepen hbo'ers waarvoor een relatieve verslechtering van de gezondheidssituatie is waargenomen

\begin{tabular}{|c|c|}
\hline \multicolumn{2}{|c|}{ Afname goede gezondheid } \\
\hline \multicolumn{2}{|c|}{ Hbo-sector } \\
\hline Kunst & $10,8 \%$ \\
\hline \multicolumn{2}{|l|}{ Leeftijd } \\
\hline 30-39 jaar & $9,4 \%$ \\
\hline \multicolumn{2}{|l|}{ Huidige status } \\
\hline Anders & $13,6 \%$ \\
\hline Student & $10,4 \%$ \\
\hline Werkloos & $11,9 \%$ \\
\hline \multicolumn{2}{|c|}{ Migratieachtergrond } \\
\hline Niet-westers & $12,6 \%$ \\
\hline Westers & $10,5 \%$ \\
\hline
\end{tabular}


Tabel 16 laat zien welke subgroepen hbo'ers met name een toename in werkstress ervaren. Werkenden in dienstverlenende, hulpverlenende, onderwijskundige en gezondheidszorg beroepen gaven op moment van bevraging relatief vaak aan meer stress te ervaren dan voorheen. Bij hbo'ers die afgestudeerd zijn in sectoren die in sterke mate voor deze beroepen opleiden, namelijk Sociale Studies, Onderwijs en Gezondheidszorg, zien we eenzelfde type beeld terug. Ook onder hbo'er uit de sector Kunst zien we een relatief sterke toename in werkstress. Dit geldt ook voor respondenten met een niet-westerse migratieachtergrond, werkenden die zowel in loondienst als als zelfstandige werken en mensen die uitsluitend buitenshuis werken.

Tabel 16. Subgroepen waarvoor een relatief sterke toename in werkstress is waargenomen

\begin{tabular}{|c|c|}
\hline Toename stress bij werk & \\
\hline \multicolumn{2}{|l|}{ Beroep } \\
\hline Dienstverlenend & $41,6 \%$ \\
\hline Hulpverlenend & $43,2 \%$ \\
\hline Onderwijskundig & $40,2 \%$ \\
\hline Gezondheidszorg & $43,5 \%$ \\
\hline \multicolumn{2}{|l|}{ Hbo-sector } \\
\hline Sociale studies & $41,4 \%$ \\
\hline Gezondheidszorg & $42,3 \%$ \\
\hline Kunst & $40,6 \%$ \\
\hline Onderwijs & $39,7 \%$ \\
\hline \multicolumn{2}{|l|}{ Migratieachtergrond } \\
\hline Niet-westers & $39,9 \%$ \\
\hline \multicolumn{2}{|l|}{ Huidige status } \\
\hline Loondienst én zelfstandig & $39,9 \%$ \\
\hline \multicolumn{2}{|l|}{ Huidige werklocatie } \\
\hline Alleen buitenshuis & $38,8 \%$ \\
\hline
\end{tabular}

Tabel 17 laat tot slot zien welke subgroepen met name een toename in stress thuis ervaren. Deze tabel schetst een gelijkaardig beeld als Tabel 15. Subgroepen die vaker dan gemiddeld een verslechtering van hun gezondheidssituatie ervaren, ervaren vaker dan gemiddeld een toename van stress thuis. Het valt buiten het bereik van dit rapport om uitspraken te doen over een mogelijke causale relatie tussen de twee indicatoren, maar dit is zeker iets waarop in een latere verdiepende fase zal worden ingegaan. Opvallend is overigens dat de huidige werklocatie (thuis en/of buitenshuis) geen bovenmatige gevolgen lijkt te hebben op de mate van stress thuis. 
Tabel 17. Groepen waarvoor een relatief sterke toename in stress thuis is waargenomen

\begin{tabular}{ll}
\hline $\begin{array}{l}\text { Toename stress thuis } \\
\text { Beroep }\end{array}$ & \\
\hline$\quad$ Artistiek & $36,0 \%$ \\
\hline Hbo-sector & \\
\hline$\quad$ Kunst & $40,4 \%$ \\
\hline Cohort & \\
\hline $\begin{array}{l}\text { Migratieachtergrond } \\
\quad \text { Niet-westers }\end{array}$ \\
\hline Huidige status & $39,4 \%$ \\
\hline Anders & $41,2 \%$ \\
\hline Student & $50,3 \%$ \\
\hline Werkloos & $50,7 \%$
\end{tabular}

\section{Situatie zelfstandigen}

In de enquête is aan zelfstandigen gevraagd (ook aan zelfstandigen die deels in loondienst werken) of ze gebruik hebben gemaakt van een reeks overheidsmaatregelen. Zo'n 38\% van de zelfstandigen gaf aan een beroep te hebben gedaan op minstens één van deze maatregelen. Tabel 18 geeft een overzicht van de afzonderlijke maatregelen waarop de respondenten een beroep hebben gedaan. Verreweg de meest gebruikte maatregel is de Tijdelijke overbruggingsregeling zelfstandig ondernemers (Tozo). Meer dan een kwart van alle zelfstandigen heeft hier een beroep op gedaan. Het aandeel zelfstandigen dat op andere maatregelen een beroep heeft gedaan (Tijdelijke Noodmaatregel Overbrugging voor Werkgelegenheid (NOW)), Tegemoetkoming Ondernemers Getroffen Sectoren COVID-19 (TOGS), betalingsuitstel van belastingen en andere niet eerdergenoemde maatregelen) is per maatregel klein, maar collectief zeker substantieel.

Tabel 18. Aandeel zelfstandigen dat een beroep heeft gedaan op verschillende overheidsmaatregelen

\begin{tabular}{|lr}
\hline Beroep gedaan op Tijdelijke Noodmaatregel Overbrugging voor Werkgelegenheid (NOW) & $3,8 \%$ \\
\hline Beroep gedaan op Tijdelijke overbruggingsregeling zelfstandig ondernemers (Tozo) & $28,2 \%$ \\
\hline Beroep gedaan op Tegemoetkoming Ondernemers Getroffen Sectoren COVID-19 (TOGS) & $4,4 \%$ \\
\hline Beroep gedaan op betalingsuitstel van belastingen & $6,8 \%$ \\
\hline Beroep gedaan op andere maatregel & $3,8 \%$
\end{tabular}

Aan zelfstandigen is verder een aantal stellingen voorgelegd over de gevolgen van de coronacrisis voor hun bedrijfsvoering. In Tabel 19 staat het aandeel respondenten weergegeven dat het enigszins of helemaal eens was met deze stellingen. Ongeveer twee derde van de zelfstandigen gaf aan door de coronacrisis opdrachten te zijn misgelopen. lets minder dan een derde zou meer overheidssteun willen. Ruim de helft gaf aan 
vertrouwen in de toekomst van hun bedrijf te hebben. En slechts 2,7\% gaf aan door de crisis personeel te hebben moeten ontslaan.

Tabel 19. Verdere situatie zelfstandigen

\begin{tabular}{|c|c|}
\hline \multicolumn{2}{|l|}{ Stellingen (\% (helemaal) eens) } \\
\hline Ik ben opdrachten misgelopen door deze crisis & $65,7 \%$ \\
\hline Ikzou meer overheidssteun kunnen gebruiken & $31,4 \%$ \\
\hline Ik heb vertrouwen in de toekomst van mijn bedrijf & $54,1 \%$ \\
\hline Ik heb personeel moeten ontslaan vanwege de crisis & $2,7 \%$ \\
\hline
\end{tabular}

\section{Situatie werklozen}

Ook aan werklozen is een aantal aanvullende vragen gesteld. Tabel 20 vat hun antwoorden op deze vragen samen. Ongeveer de helft van de werklozen gaf aan door de coronacrisis werkloos te zijn geworden. Ruim vier op de vijf werklozen gaf verder aan op moment van enquêtering op zoek te zijn naar betaald werk. Negen op de tien gaf aan het moeilijk te vinden om passend werk te vinden, en slechts $42 \%$ gaf aan vertrouwen te hebben in hun verdere carrièreperspectieven. Ruim een op de vijf gaf aan te overwegen om een eigen zaak te beginnen, en iets minder dan een derde gaf aan een nieuwe studie te overwegen.

Tabel 20. Percentage werklozen dat het eens is met de volgende stellingen.

\begin{tabular}{lr} 
Ben je mede als gevolg van de coronacrisis werkloos geworden? & $51,0 \%$ \\
\hline Ben je momenteel op zoek naar betaald werk? & $81,8 \%$ \\
\hline & \\
\hline Stellingen (\% (helemaal) eens): & $89,6 \%$ \\
\hline Het is nu moeilijk om passend werk te vinden & $42,4 \%$ \\
\hline Ik heb vertrouwen in mijn verdere carrièreperspectieven & $22,0 \%$ \\
\hline Ik overweeg een eigen zaak te beginnen & $32,2 \%$
\end{tabular}

\section{Situatie studenten}

Tabel 21 laat zien dat de meeste respondenten die na hun afgeronde hbo-opleiding aan een vervolgstudie zijn begonnen, een wo-masteropleiding of premaster (bijna driekwart) zijn gaan volgen. Nog eens $11 \%$ is met een tweede hbo-bacheloropleiding bezig, en de overige studerenden zijn verdeeld over hbo-master, wo-bachelor en andere opleidingen. Bijna één op de vijf studerende respondenten gaf op moment van bevraging aan reeds door de coronacrisis studievertraging te hebben opgelopen. Vrijwel allen gaven aan bezig te zijn met studieactiviteiten en/of in contact te zijn met hun onder- 
wijsinstelling. 14\% gaf aan een bedrijfsstage, traineeship of iets vergelijkbaars te hebben gedaan in de afgelopen periode. Van de mensen die dat niet hebben gedaan, geeft ruim $30 \%$ aan dat de plannen voor zo'n stage/werkervaringsplek zijn uitgesteld of afgeblazen ten gevolge van de crisis, en nog eens 10\% geeft aan dat dit mogelijk gaat gebeuren.

Tabel 21. Situatie studenten

\begin{tabular}{|c|c|}
\hline \multicolumn{2}{|l|}{ Niveau huidige opleiding } \\
\hline Promotietraject & $1,5 \%$ \\
\hline HBO Master & $6,9 \%$ \\
\hline W0 Master & $60,1 \%$ \\
\hline W0 Premaster & $12,4 \%$ \\
\hline HBO Bachelor & $11,3 \%$ \\
\hline WO Bachelor & $3,6 \%$ \\
\hline anders, namelijk & $4,1 \%$ \\
\hline Door corona studievertraging opgelopen & $19,3 \%$ \\
\hline \multicolumn{2}{|l|}{ Activiteiten studie } \\
\hline Colleges en/of tutorials gevolgd? & $37,1 \%$ \\
\hline Regelmatig contact gehad met docenten en/of begeleiders? & $42,9 \%$ \\
\hline Tentamens afgelegd? & $17,2 \%$ \\
\hline Andere contacten met je instelling gehad? & $19,7 \%$ \\
\hline Online lesmateriaal gebruikt? & $39,9 \%$ \\
\hline Meegedraaid in het kader van je studie in een bedrijf of organisatie? & $13,9 \%$ \\
\hline Ik heb geen van deze dingen gedaan & $3,7 \%$ \\
\hline \multicolumn{2}{|l|}{ Uitstel/afstel werkervaring } \\
\hline $\mathrm{Ja}$ & $31,0 \%$ \\
\hline Misschien & $10,5 \%$ \\
\hline Nee & $58,5 \%$ \\
\hline
\end{tabular}

\section{Situatie anderen}

Aan de kleine groep mensen die zich op het enquêtemoment in een andere situatie bevonden dan werk, werkloosheid of studie, zijn geen gestructureerde vragen gesteld om de simpele reden dat we niet vooraf konden weten wat die situaties zijn. Om hierop enig zicht te krijgen is een open vraag aan deze mensen voorgelegd, waarin ze hun situatie konden beschrijven. Het voert te ver om alle antwoorden hierop weer te geven, maar vaak hadden die te maken met arbeidsongeschiktheid, ziektewet, zwangerschaps-/ouderschapsverlof en zorgverplichtingen. 


\section{Vertrouwen in overheidsaanpak en toekomst}

Om een indruk te krijgen van hoe hbo'ers meer in het algemeen tegen de huidige situatie aankijken, is aan respondenten gevraagd aan te geven in hoeverre ze vertrouwen hebben in (1) hoe de overheid omgaat met deze crisis, en (2) dat door de versoepeling van de eerder genomen coronamaatregelen hun leven de komende tijd beter zal worden. In Tabel 22 staat weergegeven in hoeverre respondenten het enigszins of helemaal eens waren met deze stellingen. Ongeveer drie op de vijf afgestudeerden gaf aan vertrouwen te hebben in hoe de overheid met de crisis omgaat. lets minder dan de helft gaf aan te verwachten dat hun leven door de versoepelingen beter wordt.

Tabel 22. Aandeel respondenten dat vertrouwen heeft in hoe de overheid omgaat met deze crisis, en dat verbetering verwacht in hun leven door versoepeling van de maatregelen

Ik heb vertrouwen in hoe de overheid omgaat met deze crisis

Door versoepeling van de maatregelen wordt mijn leven de komende tijd beter $48,2 \%$

Tabel 23 toont de subgroepen hbo'ers die het bovengemiddeld vaak met de eerste stelling oneens waren. Hbo'ers die werkzaam zijn in artistieke beroepen en hbo'ers die werkzaam zijn in de sector Kunst, die hier vooral voor opleidt, gaven relatief vaak aan weinig vertrouwen te hebben in hoe de overheid omgaat met deze crisis. Dit geldt verder ook voor relatief oudere respondenten, afgestudeerden met een westerse of niet-westerse migratieachtergrond en afgestudeerden met een huidige status anders dan loondienst of student.

Tabel 23. Subgroepen hbo'ers die relatief weinig vertrouwen hebben in hoe de overheid omgaat met deze crisis

\begin{tabular}{ll}
\hline $\begin{array}{l}\text { Relatief weinig vertrouwen in hoe de overheid omgaat met deze crisis } \\
\text { Beroep }\end{array}$ \\
$\begin{array}{l}\text { Artistiek } \\
\text { Hbo-sector }\end{array}$ \\
$\begin{array}{l}\text { Kunst } \\
\text { Leeftijd }\end{array}$ \\
\hline 30-39 jaar & $44,6 \%$ \\
\hline Migratieachtergrond & $54,9 \%$ \\
\hline Niet-westers & $42,7 \%$ \\
\hline Westers & $42,1 \%$ \\
\hline Huidige status & $46,2 \%$ \\
\hline Anders & \\
\hline Loondienst én zelfstandig & $52,6 \%$ \\
\hline Werkloos & $53,3 \%$ \\
\hline Zelfstandig & $47,6 \%$ \\
\hline
\end{tabular}


Tabel 24 toont verder een overzicht van de subgroepen die het bovengemiddeld vaak eens zijn met de stelling dat de versoepelingen tot verbetering van hun leven zullen leiden. Opvallend weinig subgroepen wijken significant af van het algehele gemiddelde antwoord op deze stelling. Enkel werkenden in commerciële of zakelijke beroepen en jongere respondenten verwachten relatief vaker een verbetering.

Tabel 24. Groepen die relatief veel verbetering verwachten in hun leven door versoepeling van de maatregelen

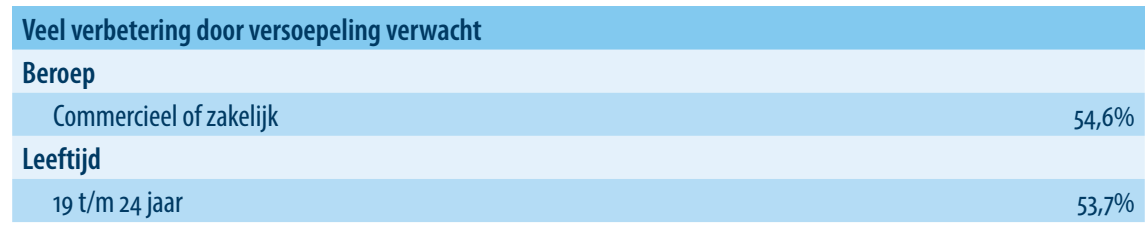

Aan het eind van de enquête is aan respondenten gevraagd om één woord te kiezen dat het beste beschrijft hoe ze zich onder de huidige omstandigheden voelen. Het idee was een meer gevoelsmatige reactie uit te lokken dan in de voorgaande voorgestructureerde vragen mogelijk was. De antwoorden hierop zijn, gewogen naar de frequentie waarmee ze genoemd zijn, samengevat in de woordenwolk dat in Figuur 1 staat afgebeeld.

Figuur 1. Afgestudeerden geven in één woord aan hoe ze zich in coronatijd voelen.

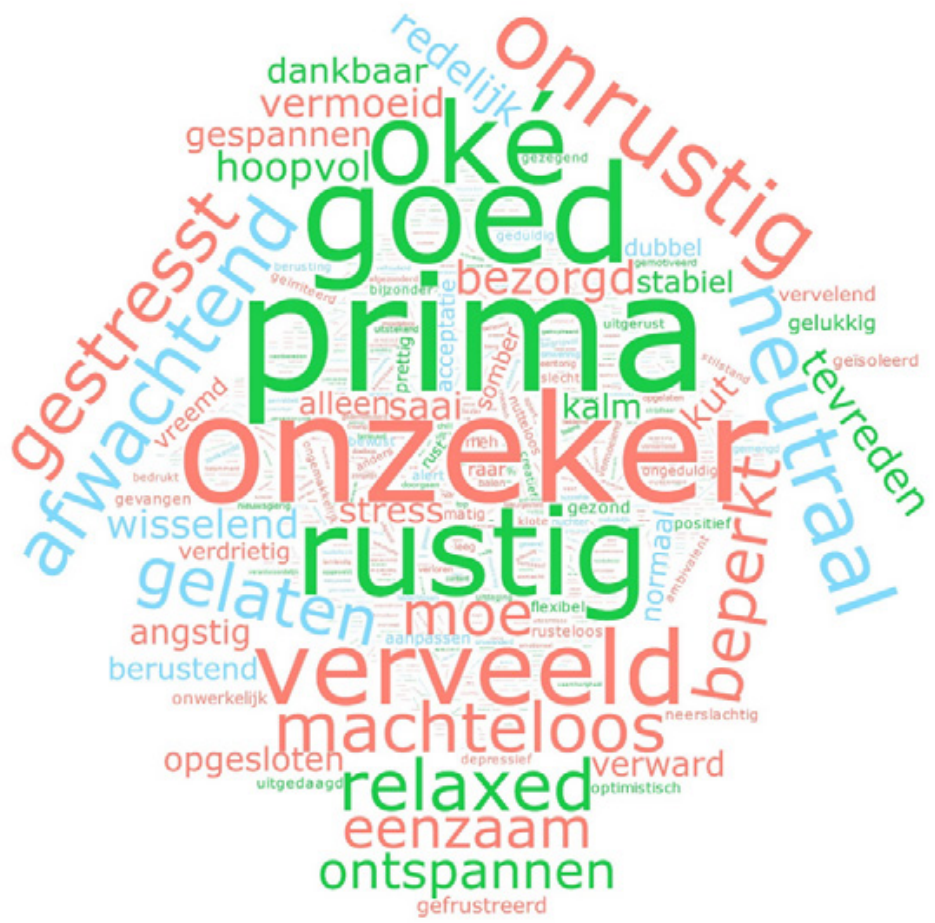

Bron: Deze woordenwolk is gegenereerd via https://www.wordclouds.com 
Uit deze woordenwolk wordt in een oogopslag duidelijk hoe verschillend de ervaringen van hbo'ers zijn in deze turbulente periode. Om de figuur leesbaarder te maken, zijn de woorden grofweg ingedeeld in drie categorieën: positief (groene kleur), neutraal (blauwe kleur) en negatief (rode kleur). Positieve en negatieve woorden komen bijna even vaak voor (respectievelijk $42 \%$ en $43 \%$ ), en neutrale woorden een stuk minder vaak (15\%). Een groot verschil tussen de negatieve woorden en positieve woorden, is de hoeveelheid verschillende woorden die voor beide categorieën worden genoemd. Er worden veel meer verschillende soorten negatieve woorden genoemd dan positieve woorden. Er blijken dus veel meer manieren te zijn waarop men de coronacrisis als vervelend ervaart, dan manieren waarop men de crisis als gunstig ervaart.

\section{Discussie en reflectie}

De gevolgen van de coronacrisis voor jongeren op de Nederlandse arbeidsmarkt worden steeds zichtbaarder. Waar de algemene werkloosheid in Nederland tussen februari en mei met slechts 0,7 procentpunten steeg (van 2,9\% naar 3,6\%) is in dezelfde periode de jeugdwerkloosheid veel harder opgelopen, van 6,3\% naar 9,5\%.. Uit het in dit rapport gepresenteerde onderzoek komt naar voren dat ook voor afgestudeerde hbo'ers sprake is van een substantiële toename in werkloosheid. Echter door de zeer gunstige uitgangspositie van deze groep vóór de coronacrisis - op 31 januari 2020 was slechts 2,2\% van de benaderde afgestudeerden werkloos - is de totale werkloosheid onder deze groep beduidend lager (4,6\% van de respondenten gaf aan in mei werkloos te zijn).

Hoewel de gevolgen van de coronacrisis over de hele linie redelijk binnen de perken zijn gebleven, zijn de gevolgen voor sommige subgroepen zorgwekkend te noemen. Het gaat dan vooral om kunstenaars, afgestudeerden met een migratieachtergrond en zelfstandigen. De gevolgen van de coronacrisis voor kunstenaars en zelfstandigen waren niet geheel onverwacht; er is immers veel publiciteit geweest over de gevolgen van de coronacrisis voor de culturele sector en voor zzp'ers. Minder gemakkelijk te verklaren zijn de negatieve uitkomsten onder afgestudeerden met een migratieachtergrond. Nader onderzoek kan hier wellicht meer licht op werpen.

Hoewel bij veel van de in dit rapport gepresenteerde cijfers de nadruk op negatieve gevolgen van de coronacrisis ligt, is het niet alleen maar kommer en kwel. De huidige crisis en nieuwe werkomstandigheden lenen zich ook voor nieuwe ontdekkingen in werkwijze en leiden zelfs bij een grote groep tot nieuwe ideeën voor het werk. Er zijn bovendien ook deelpopulaties die minder zwaar door de coronacrisis zijn getroffen, zoals duidelijk wordt uit de volledige tabellen. ${ }^{11}$

Verder is van belang te vermelden dat er ook sprake is van veel variatie binnen subgroepen. Binnen de subgroepen die het zwaarst zijn getroffen zijn er ook afgestu-

$10 \mathrm{https}: / / w w w . c b s . n l / n l-n l / n i e u w s / 2020 / 25 /$ ruim-200-duizend-werkenden-minder-sinds-maart-2020

11 De volledige tabellen zijn te vinden op www.hbomonitor.nl. 
deerden waarvoor er niet zo veel aan de hand is. Anderzijds zijn binnen de groepen waar over de hele linie relatief weinig problemen zijn, vrij veel individuen die aangeven duidelijk last van de crisis te hebben. Met het oog op effectiever beleid om de getroffen afgestudeerden beter te helpen, zijn diepgaandere analyses nodig om meer zicht te krijgen op de onderliggende oorzaken.

Tenslotte is belangrijk te vermelden dat het hier om een momentopname gaat. Ondanks dat de maatregelen nu in belangrijke mate worden versoepeld, zijn hier vanwege de angst voor het mogelijk opnieuw oplaaien van het coronavirus duidelijke limieten aan gesteld. ${ }^{12}$ Er wordt bovendien voor gewaarschuwd dat de echte piek in termen van economische gevolgen pas zal komen wanneer de steunmaatregelen van de overheid worden afgebouwd..$^{13}$ Mede hierom is het zeer onzeker hoe zaken zich nu verder ontwikkelen. Om deze reden gaan we dit onderzoek nog een aantal keer herhalen in de komende maanden. Hierdoor kunnen we een vinger aan de pols houden en met name zicht houden op de meer kwetsbare populaties onder hbo'ers.

12 https://www.vrt.be/vrtnws/nl/2020/06/10/tweede-golf-van-coronavirus-zou-wereldeconomie-erg-zwareklap-ge/

13 https://nos.nl/artikel/2337641-aantal-nieuwe-ww-uitkeringen-stijgt-minder-hard-maar-piek-komt-nog.html 
